\title{
Pengaruh Metode Pembelajaran Debate terhadap Kecerdasan Emosional pada Mata Pelajaran PPKn Kelas V SD Inpres 133 Bumi Ajo Distrik Moswaren
}

\author{
Yuyuk Sri Rahayu ${ }^{1}$, Mursalim ${ }^{2} \&$ Ihsan $^{3}$
}

\author{
Program Studi PGSD, Universitas Pendidikan Muhammadiyah Sorong, Indonesia \\ E-mail: shalatsihavisa1@gmail.com
}

\begin{abstract}
Abstrak
Penelitian ini bertujuan untuk mengetahui pengaruh metode pembelajaran debate terhadap kecerdasan emosional pada mata pelajaran PPKn kelas V SD Inpres 133 Bumi Ajo Distrik Moswaren. Penelitian ini menggunakan jenis penelitian kuantitatif dengan one group pretest-postest designs. Sampel Penelitian ini yaitu siswa kelas V berjumlah 21. Instrument yang digunakan adalaha angket dan lembar observasi. Hasil uji Reabilitas diperoleh Cronbach's untuk instrument angket debate sebesar 0,589 dan angket kecerdasan emosional 0,688. Hasil uji normalitas diperoleh nilai sig untuk instrument angket debate sebesar 0,063 dan instrument angket kecerdasan emosional sebesar 0,492, dengan hasil uji one-sample test sebesar 45,910. Hasil penelitian menunjukkan bahwa hasil analisis uji one sample $t$-test diperoleh sebesar 2,086\%., dengan nilai $t_{\text {hitung }} 45,910>t_{\text {tabel }}=1,725$ besar taraf signifikan 0,000 $<0,05$ maka keputusan hipotesis yakni H0 ditolak dan $\mathrm{H} 1$ diterim. Berdasarkan hasil analisis data dan pengujian hipotesis, maka kesimpulan penelitian ini yaitu terdapat pengaruh signifikan metode pembelajaran debat terhadap kecerdasan emosional siswa kelas V SD Inpres 133 Bumi Ajo Distrik Moswaren.
\end{abstract}

Kata Kunci: Metode Pembelajaran Debat; Kecerdasan Emosional; Pelajaran PPKn.

\begin{abstract}
This study aims to determine the effect of the debate learning method on emotional intelligence in class V PPKn subjects at SD Inpres 133 Bumi Ajo, Moswaren District. This research uses quantitative research with one group pretest-postest designs. The samples of this study were 21 st grade students. The instruments used were questionnaires and observation sheets. The reliability test results obtained by Cronbach's for a debate questionnaire instrument of 0.589 and an emotional intelligence questionnaire of 0.688. The normality test results obtained a sig value for the debate questionnaire instrument of 0.063 and an emotional intelligence questionnaire of 0.492, with a one-sample test of 45.910. The results showed that the results of the one sample t-test analysis obtained $2.086 \%$., With a value of 45.910 $>$ t table $=1.725$ with a significant level of $0.000<0.05$, the hypothesis decision that $\mathrm{HO}$ is rejected and $\mathrm{HI}$ is accepted. Based on the results of data analysis and hypothesis testing, the conclusion of this study is that there is a significant effect of the debate learning method on the emotional intelligence of the fifth grade students of SD Inpres 133 Bumi Ajo, Moswaren District.
\end{abstract}

Keywords: Methods of Debate Learning; Emotional intelligence; PPKn Learning. 


\section{PENDAHULUAN}

Pembelajaran merupakan suatu proses yang dilakukan secara sadar pada setiap individu atau kelompok untuk merubah sikap dari tidak tahu menjadi tahu sepanjang hidupnya. Proses belajar mengajar adalah suatu kegiatan yang di dalamnya terjadi proses siswa belajar dan guru mengajar dalam konteks interaktif, dan terjadi interaksi edukatif antara guru dan siswa, sehingga terdapat perubahan dalam diri siswa baik perubahan pada tingkat pengetahuan, pemahaman dan keterampilan atau sikap.

Dalam kegiatan pembelajaran terdapat dua kegiatan yang sinergik, yakni guru mengajar dan siswa belajar. Guru mengajarkan bagaimana siswa harus belajar. Sementara siswa belajar bagaimana seharusnya belajar melalui berbagai pengalaman belajar sehingga terjadi perubahan dalam dirinya baik dari aspek kognitif, psikomotorik, dan afektif. Guru yang kompeten akan lebih mampu menciptakan lingkungan yang efektif dan akan lebih mampu mengelola proses belajar mengajar, sehingga tujuan kegiatan belajar berbagai mata pelajaran dapat dicapai pada tingkat yang optimal (Zamroni, 2007). Salah satu mata pelajaran yang perlu dajarkan dengan baik adalah mata pelajara PPKn.

Untuk membelajarkan mata pelajaran PPKn, seorang guru dituntut untuk mengembangkan serta melestarikan nilai luhur dan moral yang diwujudkan dalam kepribadian serta perilaku dalam kehidupan sehari-hari siswa, baik siswa sebagai individu maupun sebagai anggota masyarakat. Sehingga pembelajaran menjadi lebih bermakna.

Namun berdasarkan hasil observasi, tanggal 25 Febuari 2020 di kelas V SD Inpres 133 Bumi Ajo Distrik Moswaren, peneliti menemukan masalah belajar siswa pada mata pelajaran PPKn. Akar penyebab rendahnya minat belajar tersebut diduga karena guru kurang tepat dalam pemilihan metode dalam pembelajaran. Guru masih cenderung menggunakan metode ceramah, dimana siswa hanya pasif dan mendengarkan materi yang disajikan. Akibatnya siswa sama sekali tidak terlibat dalam pembelajaran yang sedang berlangsung. Pada akhirnya kecerdasan emosional siswa tidak berkembang dengan baik,

Untuk meningkatkan kecerdasan emosional siswa dalam belajar, maka perlu solusi alternatif yang tepat. Salah satu solusi yang dapat diterapkan adalah penggunaan metode debate dengan pembelajaran. Metode pembelajaran debate adalah langkah operasional atau implementatif dari strategi pembelajaran yang dipilih dalam mencapai tujuan belajar. Penggunaan metode debat ini akan menunjukkan tingkat partisipasi siswa dalam proses pembelajaran. Dengan demikian kecerdasan emosional siswa dapat meningkat dengan penerapan metode ini. Dari uraian yang telah dijabarkan di atas, maka perlu suatu penelitian tentang Pengaruh Metode Pembelajaran Debate Tehadap Kecerdasan Emosional Pada Mata Pelajaran PPKn Kelas V SD Inpres 133 Bumi Ajo Distrik Moswaren.

Menurut Degeng (dalam buku Suprihatiningrum, 2010:154) metode adalah cara-cara yang berbeda untuk mencapai hasil pengajaran yang berbeda di bawah kondisi yang berbeda. Pendapat lain tentang metode pembelajaran menurut knowles (dalam buku Suprihatiningrum, 2010:154) metode adalah pengorganisasian siswa dalam upaya mencapai tujuan belajar. Definisi di atas, menunjuk metode sebagai alat untuk mencapai tujuan pengajaran. Sebagaimana disebutkan bahwa metode merupakan cara kerja yang sistematis menunjukkan sifatnya 
yang sangat operasional. Dengan demikian, dapat disimpulkan bahwa metode merupakan prinsip dasar sebuah cara kerja yang secara teknis dapat dikembangkan untuk pelaksanaan pembelajaran dikelas.

Trianto (2010:51) menyatakan bahwa "Metode pembelajaran adalah suatu perencanaan atau suatu pola yang digunakan sebagai pedoman dalam melaksanakan pembelajaran di kelas atau pembelajaran dalam tutorial." Menurut Sukmadinata \& Syaodih (2012:151) menyatakan bahwa "Metode pembelajaran adalah suatu desain yang menggambarkan proses rincian penciptaan situasi lingkungan yang memungkinkan siswa berinteraksi sehingga terjadi perubahan atau perkembangan pada diri peserta didik." Saefuddin \& Berdiati (2014:48) berpendapat bahwa "Metode pembelajaran adalah kerangka konseptual yang melukiskan prosedur sistematis dalam mengorganisasikan sistem belajar untuk mencapai tujuan belajar tertentu dan berfungsi sebagai pedoman bagi bagi perancang pembelajaran dan menurut (Wijayanto; 2017), metode debat dapat meningkatkan efektivitas pembelajaran dikelas.

Rusman (2014:144-145) berpendapat bahwa, "Metode pembelajaran adalah suatu rencana atau pola yang dapat digunakan untuk membentuk kurikulum (rencana pembelajaran jangka panjang), merancang bahan-bahan pembelajaran, dan membimbing pembelajaran di kelas atau yang lain."

Uno dan Mohamad (2013: 100) menyatakan, "Metode debat adalah metode yang dirancang untuk memecahkan masalah dari sudut pandang yang berbeda." Metode ini biasanya terdiri dari diskusi antara dua belah pihak yang mempunyai pendapat yang berbeda.

Roestiyah (2012: 148), debat adalah sebuah teknik pembicara dari pihak yang pro dan kontra menyampaikan pendapat mereka, dapat diikuti dengan suatu tangkisan atau balasan ataupun tidak, serta peserta dari tiaptiap kelompok dapat mengajukan pertanyaan kepada kelompok lain.

Melalui metode debat, setiap siswa didorong untuk mengemukakan pendapatnya melalui suatu perdebatan antar kelompok diskusi yang disatukan dalam sebuah diskusi kelas. Dalam dunia pendidikan, debat bisa menjadi metode berharga untuk meningkatkan pemikiran dan perenungan terutama jika siswa diharapkan mampu mengemukakan pendapat yang pada dasarnya bertentangan dengan mereka sendiri (Silberman 2013: 141).

Metode debat pertama kali diperkenalkan Melvin L. Silberman (Zulyeti, 2014) yang merupakan metode pengajaran yang menghadapkan siswa pada suatu permasalahan. Tujuan utama dari metode ini adalah untuk memecahkan suatu permasalahan, menjawab pertanyaan, menambah dan memahami pengetahuan siswa serta untuk membuat suatu keputusan.

Selanjutnya menurut Uno dan Mohamad (2013: 85), debat memiliki langkah-langkah sebagai berikut: (1) Guru membagi dua kelompok peserta debat yang satu pro dan satu lainnya kontra. (2) Guru memberikan tugas untuk membacakan materi yang akan didebatkan oleh kelompok di atas. (3) Setelah selesai membaca materi. Guru menunjuk salah satu anggota kelompok pro untuk berbicara dan ditanggapi atau dibalas oleh kelompok kontra, demikian seterusnya sampai sebagian besar siswa bisa mengemukakan jawabannya. (4) Sementara siswa menyampaikan gagasannya, guru menulis ide-ide dari setiap pembicaraan di papan tulis sampai sejumlah ide yang diharapkan guru terpenuhi. (5) Guru 
menambahkan konsep atau ide yang belum terungkap. (6) Dari data-data di papan tersebut, guru mengajak siswa membuat kesimpulan atau rangkuman yang mengacu pada topik yang ingin dicapai.

Kecerdasan emosional adalah kemampuan seseorang untuk menerima, menilai, mengelola, serta mengontrol emosi dirinya dan orang lain di sekitarnya. Agustian (2005:280) untuk membangun sebuah kecerdasan harus ada sinergi antara kecerdasan emosi atau emotional quotient (EQ) dan kecerdasan spiritual atau spiritual quotient (SQ). EQ bermakna hubungan manusia dengan manusia, sedangkan SQ adalah hubungan manusia dengan Tuhan. Jadi harus ada penggabungan antara rasionalitas dunia (EQ dan IQ) dan kepentingan spiritual (SQ) sehingga menjadi komprehensif.

Lima dimensi atau komponen kecerdasan emosional (EQ) menurut Goleman dalam Mar'at (2009:170) yaitu: (1) Mengenali emosi diri yaitu mengetahui apa yang dirasakan seseorang pada suatu saat dan menggunakannya untuk memandu pengambilan keputusan diri sendiri, memiliki tolok ukur yang realistis atas kemampuan diri dan kepercayaan diri yang kuat. Semakin tinggi kesadaran diri, semakin pandai dalam menangani perilaku negatif diri sendiri (2) Mengelola emosi, sangat diperlukan untuk menjaga kesejahteraan emosi. Emosi yang berlebihan dan meningkat dengan drastis dapat mengganggu dan berakibat negatif terhadap kestabilan emosional seseorang. Perilaku yang buruk akan mengakibatkan emosi yang tidak stabil (Ulatas, 2007). Seseorang yang memiliki kecerdasan emosional tidak akan dengan mudah larut kedalam perasaan. Ketika kebahagiaan datang, mereka tidak akan mengungkapkan dengan berlebihan, begitu juga kesedihan datang, mereka dapat meredam dan tidak ikut larut dalam kesedihan tersebut. (3) Motivasi diri merupakan salah satu hak yang penting dalam kehidupan manusia, begitu juga dengan pendidik yang berkeinginan untuk dapat memunculkan motivasi pada diri siswa. Peserta didik dengan tingkat kecerdasan tinggi tetapi kurang mendapat motivasi, juga akan berpengaruh terhadap prestasi yang kurang maksimal. Prestasi akan baik jika diikuti dengan motivasi yang kuat pula. (4) Mengenali emosi orang lain yakni kemampuan untuk mengenali emosi orang lain disebut juga empati. Kemampuan mengenali emosi orang lain (empati) adalah merasakan yang dirasakan orang lain, mampu memahami perspektif mereka, menumbuhkan hubungan saling percaya dan menyelaraskan diri dengan bermacammacam orang.

\section{METODE PENELITIAN}

Jenis penelitian yang digunakan dalam penelitian kuantitatif dengan metode eksperimen. Metode eksperimen yang digunakan dalam penelitian ini adalah one group pretest-postest design. Variabel dalam penelitian ini terdiri atas dua variabel yakni variabel bebas adalah variabel yang mempengaruhi atau yang menjadi sebab perubahannya atau timbulnya variabel dependent (terikat) sedangkan variabel terikat yaitu variabel yang dipengaruhi atau yang menjadi akibat karena adanya variabel bebas.

Dalam penelitian ini yang menjadi variabel bebasnya yaitu metode pembelajara debate dan yang menjadi variabel terikat yaitu kecerdasan emosional. Populasi dalam penelitian ini adalah seluruh siswa Kelas V SD Inpres 133 Bumi Ajo Sorong Selatan. Sedangkan sampel penelitian adalah seluruh siswa kelas V SD Inpres 133 Bumi Ajo yang berjumlah 21 siswa yang terdiri dari 8 siswa 
laki-laki dan 13 siswa perempuan. Teknik penarikan sampel menggunakan teknik sampling jenuh yaitu metode penarikan sampel bila semua anggota populasi dijadikan sebagai sampel. Instrumen penelitian ini menggunakan angket kecerdasan emosional, angket metode pembelajaran debat, dan lembar observasi yang terlebih dilakukan uji validasi ahli dan uji realibilitas. Sedangkan analis data menggunakan uji t yang terlebih dahulu di uji prasyarat dengan uji Normalitas bertujuan untuk mengetahui apakah penyebaran data berada dalam posisi kurva norma. Uji normalitas yang digunakan dalam penelitian ini adalah Shapiro wilk.

\section{HASIL DAN PEMBAHASAN}

Validasi adalah suatu ukuran yang menunjukan kevalidan atau kesalahan suatu instrument sehingga sebuah instrument dikatakan valid dan layak digunakan, Sebelum instrument dipakai dala tahap penelitian telebih dahulu peneliti melakukan validasi instrument. Tujuan validasi instrument ini adalah agar instrument digunakan peneliti valid dan layak digunakan saat penelitian. Instrument peneliti ini divalidasi oleh seorang ahli dosen atau satu professional judgment.

Adapun instrument yang divalidasi pada penelitian ini terdiri atas tiga instrument yaitu, lembar Angket, Observasi dan RPP. Pada lembar Angket dan observasi ini peneliti mencakup lembar Angket dan Observasi aktivitas siswa dan lembar Observasi guru kemudian satunya lagi lembar RPP. Hasil dari masing-masing instrument peneliti dapat dijelaskan sebagai berikut.

Penerapan atau penggunaan lembar angket, observasi dan RPP aktivitas siswa dimaksudkan untuk mendapat data guru dalam proses pembelajaran yang menggunakan LKS, berdasarkan hasil validasi angket,observasi dan RPP aktivitas siswa dan guru oleh Ekspert judgment mendapatkan skor 17 . Berdasarkan kriteria penilaian validasi berada pada rentang nilai $12<\mathrm{x}<16$ dengan kategori nilai baik. Jadi kesimpulannya instrument lembar angket, observasi dan RPP siswa dan guru dapat digunakan. Sedangkan penerapan instrument lembar angket siswa dimaksudkan untuk mendapat data aktivitas siswa dimaksudkan untuk mendapatkan siswa selama mengikuti pembelajaran yang menggunkan angket, berdasarkan hasil validasi lembar angket aktivitas siswa oleh ekspert judgment mendapatkan skor 19. berdasarakan kriteria penelitian validasi berada pada rentang nilai $16<\mathrm{x}<20$ dengan kategori nilai sangat baik. Jadi kesimpulannya instrument lembar angket aktivitas siswa dapat digunakan.

Selanjutnya menvalidasi instrument angket, dengan tujuan agar instrument tujun agar instrument layak atau valid digunakan pada saat penelitian, berdasrkan hasil belajar mendapat skor 19. berdasarkn kriteria penelitian validasi berada pada rentang nilai $16<\mathrm{x}<20$ dengan kategori nilai sangat baik. Jadi kesimpulannya instrument angket hasil belajar dapat digunakan tanpa revisi.

Selain menvalidasi tiga instrument penelitian diatas, penelitian juga melakukan validasi terhadap perangkat pembelajaran yakni RPP dan LKS. Tujuan validasi RPP ini dimaksud agar dapat mengetahui apkah materi pembelajran disekolah yang sedang berlangsung sesuai dengan materi pembelajaran yang akan diteliti oleh peneliti. Berdasarkan hasil validasi RPP oleh Ekspert Judgment mendapat skor 19 dalam kriteri penilaian validasi berada pada rentang nilai $16<\mathrm{x}<20$ dengan kategori nilai sangat baik, sehingga disimpulkan RPP dapat digunakan dengan tanpa revisi. 
Sedangkan validasi Observasi dimaksudkan agar proses pembelajaran sesuai dengan langkah-langkah pembelajaran dalam observasi dan sajian Penerapan atau penggunaan instrument lembar observasi. Berdasarkan hasil validasi observasi oleh ekspert judgment mendapatkan skor. Dalam kriteria penilaian validasi berada pada rentang nilai dengan kategori nilai sangat baik, sehingga dapat disimpulkan Observasi dapat digunakan.

Uji reabilitas digunakan untuk menguji apakah data tersebut reliabel atau tidak. Penguji realibilitas instrumen berdasarkan perhitungan uji reliabiitas terhadap instrument angket dan test menggunakan cronbach alpha adalah:

Tabel 1. Uji reabilitas Pre-test Angket Metode Debate

\begin{tabular}{ll}
\hline \multicolumn{2}{c}{ Reliability Statistics } \\
\hline Cronbach's Alpha & \multicolumn{2}{c}{ N of Items } \\
0.589 & 18 \\
\hline
\end{tabular}

Hasi perhitungan reabilitas pada tabel 1 di atas diperoleh nilai sebesar 0,589 dari total item 18.

Tabe 2. Uji reliabelitas Post-Test Angket Kecerdasan Emosional

\begin{tabular}{ll}
\hline \multicolumn{2}{c}{ Reliability Statistics } \\
\hline Cronbach's Alpha & N of Items \\
0.688 & 14 \\
\hline
\end{tabular}

Hasil perhitungan uji reliabelitas pada tabel 2 di atas yang diperoleh nilai sebesar 0,688 dengan demikian dikatakan reliabel. Deskriptif data hasil penelitian meliputi data angket Pre test, data angket Post Test, data angket adalah skor awal hasil belajar siswa, sedangkan nilai angket skor akhir hasil belajar siswa. Untuk mengetahui pengaruh metode pembelajaran debate terhadap kecerdasan emosional yang digunakan dapat dilihat dari mean (nila rata-rata) dan modus (nilai yang sering muncul) hasil belajar.

Data pre test merupakan data hasil belajar awal siswa diperoleh sebelum diberikan perlakuan dan data postest diperoleh sesudah diberi perlakuan yaitu dengan metode pembelajaran debate terhadap kecerdasan emosional pada mata pelajaran PPKn.

Hasil angket debate pre-test yang menggunakan metode pembelajaran debate terhadap kecerdasan emosional. Frekuensi hasil angket metode debat pada tabel berikut.

Tabel 3. Distribusi Frekuensi Pre-test Angket Metode Debate

\begin{tabular}{lll}
\hline & \multicolumn{1}{c}{ Statistics } & \\
\hline & & \\
$\mathrm{N}$ & Valid 18 \\
& Missing & 21 \\
\hline & Mean & 0 \\
Median & 65.76 \\
Mode & 65.00 \\
& Sum & 65 \\
& 1381 \\
\hline
\end{tabular}

Berdasarkan tabel 3 diatas, hasil angket pengaruh debate diperoleh mean adalah 65 Adapun mode angket pengaruh debate adalah 65,76. Hasil angket post-test setelah mendapat perlakuan, yakni dengan menggunakan metode pembelajaran debate tehadap kecerdasan emosional. Frekuensi hasil angket metode debat pada tabel berikut.

Tabel 4. Distribusi Frekuensi Post-Test Angket kecerdasan Emosional

\begin{tabular}{llll}
\hline \multicolumn{3}{c}{ Statistics } & \\
\hline $\mathrm{N}$ & Valid & 21 \\
& Missing & 0 \\
\hline Mean & & 61.95 \\
Median & 62.00 \\
Mode & & 64 \\
Sum & & 1301 \\
\hline
\end{tabular}

Berdasarkan tabel 4 di atas, hasil angket kecerdasan emosional diperoleh mean adalah 61,95 Adapun mode angket kecerdasan emosional adalah 64.

Uji normalitas dilakukan untuk membuktikan bahwa sampel tersebut berasa dari populasi yang berdistribusi normal atau tidak. Berdasarkan perhitungan uji normalitas menggunakan rumus Shapiro wilk dengan taraf signifikan seluruh proses perhitungan dilakukan dengan bantuan program SPSS V26.0 statistik for windows. Uji normaitas 
ini dilakukan terhadap skor masing-masing kriteria yang digunakan adalah jika hasil > 0,05 maka distribusi frekuensi tersebut normal, sebaiknya jika hasil $<0,05$ maka distribusi frekuensi tidak normal. Berikut ini hasil rangkuman hasil uji normalitas.

Tabel 5. Rangkuman Hasil Uji Normalitas

\begin{tabular}{|c|c|c|c|}
\hline \multicolumn{4}{|c|}{ Tests of Normality } \\
\hline & \multicolumn{3}{|c|}{ Shapiro-Wilk } \\
\hline & Statistic & Df & Sig. \\
\hline Debate & .913 & 21 & 0.063 \\
\hline $\begin{array}{l}\text { Kecerdasan } \\
\text { emosional }\end{array}$ & .959 & 21 & 0.492 \\
\hline
\end{tabular}

Berdasarkan data dari tabel 5 di atas dapat diketahui bahwa nilai signifikan (sig) pada angket pengaruh debate $0,063>0,05$ dan angket kecerdasan emosional 0,492> 0,05 maka kedua data tersebut berdistribusi normal, dan dapat digunakan sebagai syarat uji hipotesis.

Setelah uji prasyarat (uji normalitas) terpenuhi, maka selanjutnya adalah uji hipotesis. Dalam penelitian ini, pengujian hipotesisis menggunakan Uji t (one sample test). Kriteria yang digunakan adalah apabila nilai thitung > ttabel atau sig < 0,05 maka $\mathrm{H} 1$ diterima dan HO ditolak.

Tabel 6. Hasil Uji One Sample T-test

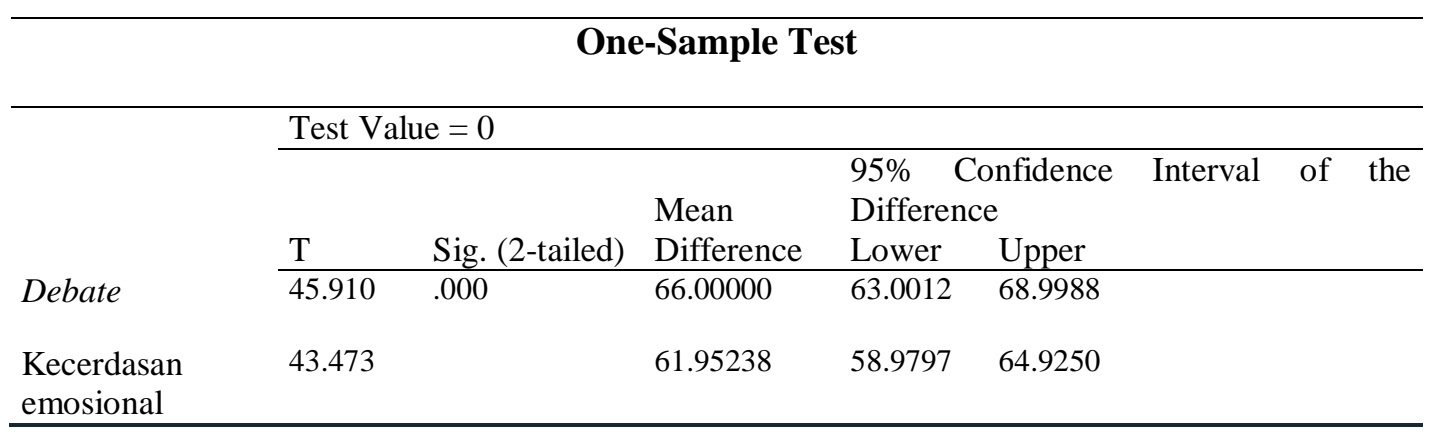

Berdasarkan tabel 6 di atas, hasil analisis uji One Sample t-test menunjukan bahwa nilai antara pengaruh metode debate sebesar 45,910 dengan Sig. (2-tailed) sebesar 0,000. dikarenakan taraf signifikan yang telah ditetapkan yaitu sebesar $0,000<$ 0,05 dan t hitung sebesar 45,910 untuk taraf signifikan $5 \%$ dengan $\mathrm{df}=21-1=20$ diperoleh ttabel 43,473. Artinya metode debate berpengaruh terhadap kecerdasan emosional.

\section{KESIMPULAN}

Berdasarkan hasil penelitian yang didasarkan pada analisis data dan pengujian hipotesis, maka kesimpulan penelitian ini yaitu terdapat pengaruh signifikan metode pembelajaran debat terhadap kecerdasan emosional siswa kelas V SD Inpres 133 Bumi Ajo Distrik Moswaren. Hal ini ditunjukan oleh hasil analisis uji one sample t-test yaitu sebesar $2,086 \%$., dengan nilai $\mathrm{t}_{\text {hitung }} 45,910>\mathrm{t}_{\text {tabel }}=$ 1,725 besar taraf signifikan $0,000<0,05$ maka $\mathrm{H} 0$ ditolak dan $\mathrm{H} 1$ diterima.

\section{DAFTAR RUJUKAN}

Agustian, Ary Ginanjar. (2005). Rahasia Sukses Membangun Kecerdasan Emosi dan Spiritual ESQ. Jakarta: Arga Publisghing.

Anisah, A. S., \& Suntara, H. (2020). Penerapan Metode Pembelajaran Debate Untuk Meningkatkan Kecerdasan Emosional Siswa. Jurnal Pendidikan UNIGA, 14(1), 254-267.

Gitosaroso, Moh. Kecerdasan Emosi Dalam Tasawuf. Jurnal Khatulistiwa, Vol. 2 No. 2 (September 2012).

Guleman, Daniel. (2006). Emotional Intelligence. Jakarta: PT Gramedia Pustaka Utama.

Imakulata, J. E. (2019). Peningkatan 
kecerdasan emosional melalui model pembelajaran debat kelas V SDK St. Mikael Surabaya (Doctoral dissertation, Wijaya Kusuma Surabaya University).

Mar'at, Samsunuwiyati. 2005. Psikologi Perkembangan. Bandung: PT. Remaja Rosdakarya.

Roestiyah. (2012). Strategi Belajar Mengajar. Jakarta: Rineka Cipta.

Shoimin, Aris. (2014). 68 Model Pembelajaran Inovatif dalam Kurikulum 2013. Yogyakarta: Ar-Ruzz Media.

Silberman, Melvin L. (2013). Active Learning (101 Cara Belajar Siswa Aktif). Bandung: Nusa Media.

Suprihatiningrum, J. (2013). Strategi Pembelajaran Teori \& Aplikasi. Arruzz Media: Jogjakarta.

Uno, H. B., \& Mohamad, N. (2011). Belajar dengan Pendekatan PAILKEM: Pembelajaran Aktif Inovatif Lingkungan Kreatif Menarik. Jakarta: Bumi Aksara.

Ulutaş, İ., \& Ömeroğlu, E. (2007). The effects of an emotional intelligence education program on the emotional intelligence of children. Social Behavior and Personality: an international journal, 35(10), 1365-1372.

Wijayanto, P. A., Utaya, S., \& Amirudin, A. (2017). Efektivitas Metode Debat Aktif dan Strategi Penerapannya dalam Mengoptimalkan Pembelajaran Geografi. Jurnal Pendidikan dan Kebudayaan, 2(1), 99-116.

Yulianto, A., Mahmud, E., \& Kumullah, R. (2020). Pengaruh Model Guided Note Taking (GNT) Terhadap Kecerdasan Emosional Siswa Mata Pelajaran PPkn Kelas V SD Negeri 26 Kota Sorong. Jurnal Papeda: Jurnal Publikasi Pendidikan Dasar, 2(2), 64-70.

Zulyetti, Z. (2014). Penerapan Metode Active debate dalam Meningkatkan Keterampilan Berbicara pada Mata Pelajaran Bahasa Indonesia. JUPIIS: JURNAL PENDIDIKAN ILMU-ILMU SOSIAL, 6(1), 14-21. 